\title{
Pathogen accumulation cannot undo the impact of invasive species
}

\author{
Nahuel Policelli - Mariana C. Chiuffo · Jaime Moyano • Agostina Torres • \\ Mariano A. Rodriguez-Cabal · Martín A. Nuñez
}

Received: 17 September 2016/ Accepted: 12 April 2017

(C) Springer International Publishing Switzerland 2017

Pathogen accumulation can decrease, increase, or not change invasive species abundance, but their impacts may persist in all scenarios.

The role of pathogens in biological invasions has usually been placed in the context of two hypotheses, enemy release and biotic resistance (Gilbert and Parker 2006). However, recent research has suggested that pathogen accumulation over time can suppress invasive species (Diez et al. 2010; Dostál et al. 2013; Flory and Clay 2013; Stricker et al. 2016). When spreading, non-native plants increase their chances of finding different pathogens species and environmental conditions that favor infection. Consistently, pathogen accumulation has been observed in nature (Mitchell et al. 2010); with time non-native species acquire more enemies (Hawkes 2007, but see Day et al. 2015). In general, non-native plants can acquire and accumulate pathogens by three possible mechanisms: (1) host shift: the non-native species becomes a host for a native pathogen. (2) Co-invasion: the natural enemies

Nahuel Policelli and Mariana C. Chiuffo have contributed equally to this work.

N. Policelli · M. C. Chiuffo - J. Moyano ·

A. Torres - M. A. Rodriguez-Cabal · M. A. Nuñez $(\square)$ Grupo de Ecología de Invasiones, INIBIOMA,

Universidad Nacional del Comahue, CONICET, Avenida de los Pioneros 2350, San Carlos de Bariloche, Río Negro, Argentina

e-mail: nunezm@gmail.com of the non-native species can be intentionally or accidentally introduced in the new range (Diez et al. 2010). (3) New introduction: non-native species encounter a non-native pathogen. Here, we argue that pathogen accumulation may not be an effective mechanism to control non-native invasive species populations, and, even when doing so, it may be too late for native ecosystems because the ecological impact has already occurred (Simberloff and Gibbons 2004).

Spontaneous crashes of non-native invasive species populations in natural conditions do occur and have been associated with negative effects of pathogens; however, little is known about the causes driving these phenomena (Simberloff and Gibbons 2004). For instance, the population decline of a highly invasive shrub, Lonicera maackii, was related to a pathogen outbreak of the honeysuckle leaf blight (Boyce et al. 2014). However, this outbreak could not be identified as the cause or consequence of the population decline of L. maackii (Boyce et al. 2014). It has been shown experimentally that seed viability of $L$. maackii can be reduced by pathogen accumulation (Orrock et al. 2012). In another experiment, fungal pathogen accumulation reduced the leaf area, total biomass, and seed production of a highly invasive annual grass, $\mathrm{Mi}$ crostegium vimineun (Flory et al. 2011; Stricker et al. 2016). Even when individual performance can be affected by pathogens, current evidence of invasive species suppression by pathogen accumulation is inconclusive (Flory and Clay 2013; Stricker et al. 2016). 
For several reasons, we dispute the idea that pathogen accumulation could control widely distributed invasive species. First, when pathogen accumulation reaches a high point (i.e., large number of enemies) the invasive species may already be widely distributed and therefore harder to control (Lovett et al. 2016). Consistently, Diez et al. (2010) found that the non-native species experiencing stronger negative soil feedbacks were more widely distributed. Second, pathogens are unlikely to control invasive species spread because pathogens are generally absent at the invasion front. The low abundance and patchy distribution of invasive species at the invasion vanguard result in transmission failure or local extinctions of the pathogen and hence a prevalence of uninfected plants (Phillips et al. 2010). Third, as pathogens accumulate over time, positive interactions may accumulate as well. For example, below-ground mutualisms also change and accumulate with time (Reinhart and Callaway 2006; Morris et al. 2007), which could compensate for negative effects of pathogens and even facilitate the invasion process. Fourth, invasive plants are known to accumulate pathogens at a slower rate than do non-invasive plants. Klironomos (2002) found that highly invasive plant species accumulate pathogens at low rate, not experiencing negative feedback until they achieve high densities. Fifth, invasive plants may transfer their pathogens (native or non-native) to the native community, which in turn disfavors native species and favors the invader itself (Kelly et al. 2009; Flory et al. 2011; Stricker et al. 2016). Therefore, a role for pathogen accumulation in limiting invaders abundance seems very rare and one of a number of possible outcomes.

Once pathogens accumulate, invasive species abundance may decrease, increase, or not change (summarized in Fig. 1) but the ecological impact generated by the species may persist over time. The impacts of invasive species are pervasive, varied, and can increase, decrease, or qualitatively change over

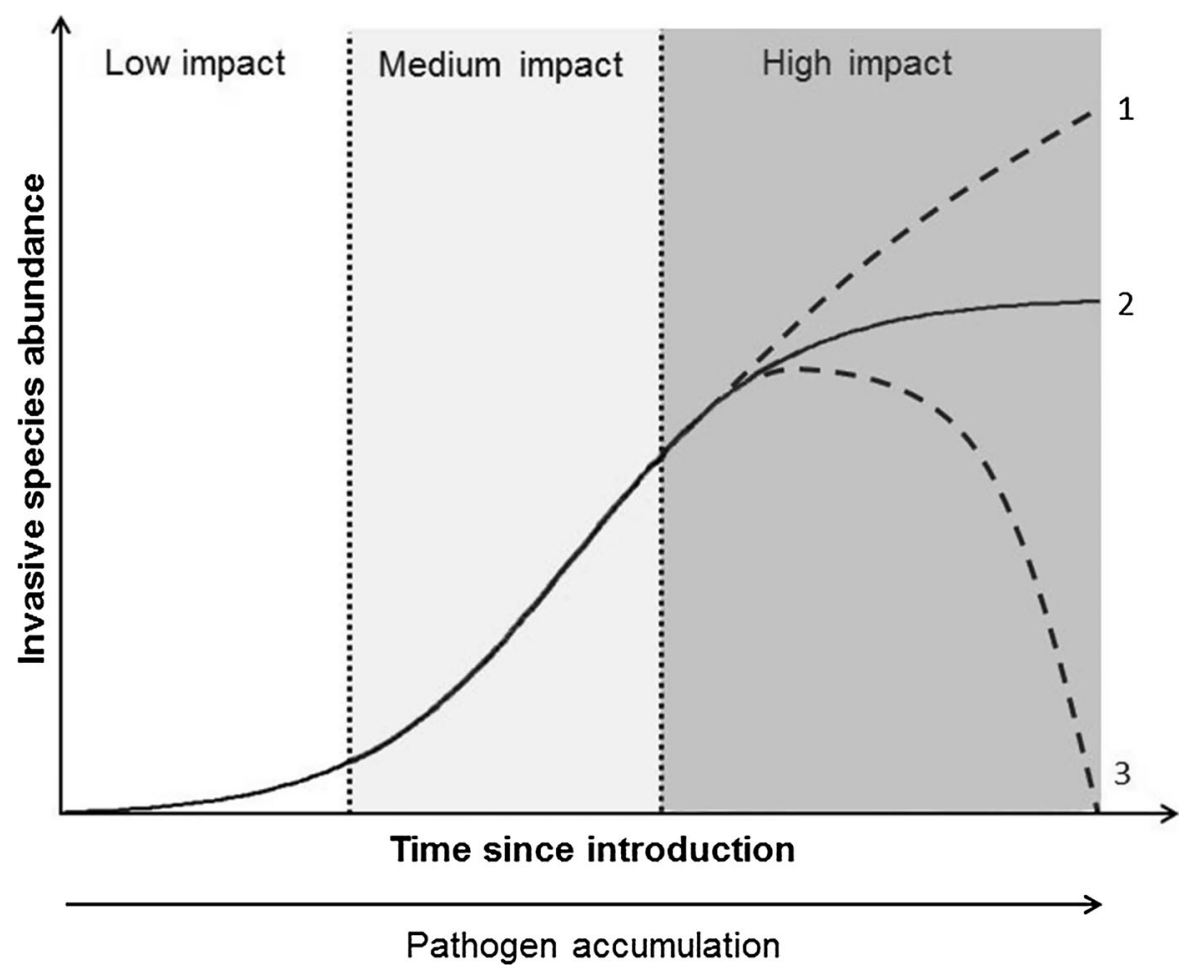

Fig. 1 Three possible outcomes of pathogen accumulation on invasive species abundance. (1) Pathogen accumulation increases invasive species abundance due to "spillback" of pathogens on native species, which results in native species decline and thus reduced competition for invasive species (Flory and Clay 2013). (2) Pathogen accumulation does not affect the abundance of invasive species, invasive species population may be regulated by other mechanisms. (3) Pathogen accumulation reduces the abundance of invasive species, even to the extreme of population crash (rare natural events). In all three possible outcomes, the ecological cumulative impact generated by the invasive species may be persistent in time 
time (Strayer et al. 2006). Some impacts of invasive species may be transient, while others can generate large ecological changes that last long after their disappearance (i.e., legacy effect) (Corbin and D'Antonio 2012; Dickie et al. 2014). Impacts can range from shifts in the relative abundance of species within a community up to local extinctions of native species (Downey and Richardson 2016), and changes in biogeochemical cycles and disturbance regimes (Ehrenfeld 2010; Corbin and D'Antonio 2012). Some invaders' impacts on ecological processes can even drive the community to a different stable state (Gaertner et al. 2014).

Recently it has been proposed that pathogen accumulation over time can reduce the impact of invasive species (Dostál et al. 2013; Stricker et al. 2016). According to Flory et al. (2011), this could happen because a decline in the invader's density could lead to a point where the invasive species are no longer problematic. Dostál et al. (2013) found that the impact of invasive species on native species richness decreased over time, but there is no direct evidence that pathogens are responsible of the reduction in impact. Stricker et al. (2016) specifically suggest that pathogen accumulation may reduce the negative impact of invasive species, but no data supports this idea. Therefore, hard evidence that pathogens can reduce the impact of invasive species is still lacking.

In conclusion, waiting for pathogens to regulate invasive species may not be an effective method to control them. Active management of invasive species is required. Some aspects of invasion can be transient, but their impacts may be long lasting owing to their legacy effects, even when they are controlled by new or co-evolved enemies. Even when pathogen accumulation does control invasive species, the invader may already have changed the native ecosystem irreversibly.

\section{References}

Boyce RL et al (2014) The beginning of the end? Extensive dieback of an open-grown Amur honeysuckle stand in northern Kentucky, USA. Biol Invasions 16:2017-2023

Corbin JD, D'Antonio CM (2012) Gone but not forgotten? Invasive plants' legacies on community and ecosystem properties. Invasive Plant Sci Manag 5:117-124
Day NJ, Dunfield KE, Antunes PM (2015) Temporal dynamics of plant-soil feedback and root-associated fungal communities over 100 years of invasion by a non-native plant. J Ecol 103:1557-1569

Dickie IA, St John MG, Yeates GW, Morse CW, Bonner KI, Orwin K, Peltzer DA (2014) Belowground legacies of Pinus contorta invasion and removal result in multiple mechanisms of invasional meltdown. AoB Plants 6:plu056

Diez JM, Dickie IA, Edwards G, Hulme PE, Sullivan JJ, Duncan RP (2010) Negative soil feedbacks accumulate over time for non-native plant species. Ecol Lett 13:803-809

Dostál P, Müllerová J, Pyšek P, Pergl J, Klinerová T (2013) The impact of an invasive plant changes over time. Ecol Lett 16:1277-1284

Downey PO, Richardson DM (2016) Alien plant invasions and native plant extinctions: a six-threshold framework. AoB Plants 8:plw047

Ehrenfeld JG (2010) Ecosystem consequences of biological invasions. Annu Rev Ecol Evol Syst 41:59-80

Flory SL, Clay K (2013) Pathogen accumulation and long-term dynamics of plant invasions. J Ecol 101:607-613

Flory SL, Kleczewski N, Clay K (2011) Ecological consequences of pathogen accumulation on an invasive grass. Ecosphere 2:1-12

Gaertner M, Biggs R, Te Beest M, Hui C, Molofsky J, Richardson DM (2014) Invasive plants as drivers of regime shifts: identifying high-priority invaders that alter feedback relationships. Divers Distrib 20:733-744

Gilbert G, Parker I (2006) Invasion and the regulation of plant populations by pathogens. In: Cadotte MC, Mcmahon SM, Fukami T (eds) Invasion and the regulation of plant populations by pathogens. Conceptual ecology and invasion biology: reciprocal approaches to nature. Springer, Berlin, pp 289-305

Hawkes CV (2007) Are invaders moving targets? The generality and persistence of advantages in size, reproduction, and enemy release in invasive plant species with time since introduction. Am Nat 170:832-843

Kelly D, Paterson R, Townsend C, Poulin R, Tompkins D (2009) Parasite spillback: a neglected concept in invasion ecology? Ecology 90:2047-2056

Klironomos JN (2002) Feedback with soil biota contributes to plant rarity and invasiveness in communities. Nature 417:67-70

Lovett GM et al (2016) Nonnative forest insects and pathogens in the United States: impacts and policy options. Ecol Appl 26:1437-1455

Mitchell CE, Blumenthal D, Jarošík V, Puckett EE, Pyšek P (2010) Controls on pathogen species richness in plants' introduced and native ranges: roles of residence time, range size and host traits. Ecol Lett 13:1525-1535

Morris WF et al (2007) Direct and interactive effects of enemies and mutualists on plant performance: a meta-analysis. Ecology 88:1021-1029

Orrock JL, Christopher CC, Dutra HP (2012) Seed bank survival of an invasive species, but not of two native species, declines with invasion. Oecologia 168:1103-1110

Phillips BL, Kelehear C, Pizzatto L, Brown GP, Barton D, Shine R (2010) Parasites and pathogens lag behind their host during periods of host range advance. Ecology 91:872-881 
Reinhart KO, Callaway RM (2006) Soil biota and invasive plants. New Phytol 170:445-457

Simberloff D, Gibbons L (2004) Now you see them, now you don't! population crashes of established introduced species. Biol Invasions 6:161-172

Strayer DL, Eviner VT, Jeschke JM, Pace ML (2006) Understanding the long-term effects of species invasions. Trends Ecol Evol 21:645-651
Stricker KB, Harmon PF, Goss EM, Clay K, Luke Flory S (2016) Emergence and accumulation of novel pathogens suppress an invasive species. Ecol Lett 19:469-477 